Profit: Jurnal Kajian Ekonomi dan Perbankan 2 (2) 2018. P: 85-106

PROFIT : JURNAL KAJIAN EKONOMI DAN PERBANKAN https://ejournal.unuja.ac.id/index.php/profit

E-ISSN : 2597-9434, ISSN: 26854309

\title{
IMPLEMENTASI PRODUKSI DALAM MENGHADAPI REVOLUSI INDUSTRI (STUDI PADA PROVIDER DI INDONESIA)
}

\author{
Hendra Yulia Rahman, \\ Wartoyo*
}

- IAIN Syekh Nur Jati

- STAIN Al-Fatah Jayapura

\section{Abstract:}

Penelitian ini membahas mengenai pesatnya perkembanan revolusi industry yang dihadapi oleh teknologi informasi termasuk provider.Perkembangan dunia teknologi informasi pada masa sekarang ini berpengaruh sangat besar terhadap setiap aspek kehidupan manusia. Semua hal yang dulu dikerjakan secara manual kini sudah terdapat versi digitalnya. Bahkan aspek-aspek yang menyangkut kegiatan hidup sehari-hari hampir semuanya dapat diakses melalui jejaring dunia maya. Begitu juga dunia usaha atau bisnis yang merupakan sektor paling besar yang terdampak dari peralihan era industrialisasi saat ini yang menuntut semuanya serba cepat, tepat dan transparan.

Permasalahan yang timbul adalah pada masa sekarang ini teori dan konsep produksi bagi dunia usaha masih sederhana dan tidak lagi sesuai dengan kondisi saat ini. Lalu bagaimanakah strategi dan manajemen produksi yang tepat untuk sekarang ini yang mengalami pergeseran sedemikian cepat, sehingga tidak lagi sesuai dengan teori dan konsep produksi modern.

Dari kajian ini diperoleh pemahaman bahwa bila suatu perusahaan tidak secara cepat menyesuaikan diri dengan trend yang ada, maka bisa dipastikan perusahaan tersebut hanya tinggal menghitung hari saja dari ancaman kebangkrutan. Telah banyak contoh yang terjadi, misalnya pada industri ritel, dimana para pelaku besar seperti Matahari Departement Store, Ramayana, Giant dan masih banyak lagi perusahaan sejenis yang terpaksa menutup sebagian gerainya karena mulai kalah bersaing dengan market online yang sekarang banyak sekali bermunculan.

Email :wartoyo@gmail.com Keyword: Sertifikasi halal, halal tourism, maqashid al-syariah 


\section{Pendahuluan}

Perkembangan dunia teknologi informasi pada masa sekarang ini berpengaruh sangat besar terhadap setiap aspek kehidupan manusia. Semua hal yang dulu dikerjakan secara manual kini sudah terdapat versi digitalnya. Bahkan aspek-aspek yang menyangkut kegiatan hidup sehari-hari hampir semuanya dapat diakses melalui jejaring dunia maya.

Terlebih lagi dunia usaha atau bisnis yang merupakan sektor paling besar yang terdampak dari peralihan era industrialisasi saat ini yang menuntut semuanya serba cepat, tepat dan transparan. Sebab bila suatu perusahaan tidak secara cepat menyesuaikan diri dengan trend yang ada, maka bisa dipastikan perusahaan tersebut hanya tinggal menghitung hari saja dari ancaman kebangkrutan. Telah banyak contoh yang terjadi, misalnya pada industri ritel, dimana para pelaku besar seperti Matahari Departement Store, Ramayana, Giant dan masih banyak lagi perusahaan sejenis yang terpaksa menutup sebagian gerainya karena mulai kalah bersaing dengan market online yang sekarang banyak sekali bermunculan seperti jamur di musim hujan. Inilah yang disebut dengan revolusi industri yang kini sudah memasuki era revolusi industri 4.0

Revolusi Industri 4.0 menghasilkan perubahan yang supercepat, eksponensial, dan disruptif. Industri-industri lama "dirusak" (creativedestruction) sehingga menghasilkan industri-industri baru dengan pemain yang baru, model bisnis baru, dan value proposition baru. Perubahan disruptif Industri 4.0 ini memiliki kekuatan "membilas" industri lama: ritel tradisional dibilas oleh ecommerce; media cetak dibilas oleh media online; layanan taksi tradisional dibilas layanan taksi berbasis sharing economy; layanan telekomunikasi dibilas oleh layanan OTT (over-the-top) seperti WhatsApp; mass manufacturing bakal dibilas oleh additive manufacturing yang tailor-made dengan adanya teknologi 3D printing; bahkan nilai tukar mata uang negara akan dibilas oleh cryptocurrency (Blockchain). ${ }^{1}$ Hampir semua bidang atau sektor industri akan secara langsung maupun tidak langsung terkena imbas dari revolusi industri 4.0 ini mulai dari faktor-faktor produksi hingga ke strategi distribusi dan pemasaran.

Pada bidang produksi, yang secara sederhana bisa diartikan sebagai setiap kegiatan dalam sebuah organisasi bisnis yang dimaksudkan untuk mendapatkan nilai tambah

1Tatik Suryani, Penguatan Peran Perguruan Tinggi dalam Pemberdayaan Masyarakat di Era Industri 4.0, Procising Seminar Nasional Hasil Pengabdian Masyarakat (SENIAS) Universitas Islam Madura 2018.

\begin{tabular}{l|l}
\hline 87 & Profit : Jurnal Kajian Ekonomi dan Perbankan
\end{tabular} 
(added value) yang secara lebih konkrit sebagai output berupa hasil keuntungan (profit). Untuk mendapatkan keuntungan tersebut, sebuah perusahaan atau organisasi bisnis biasanya melakukan kegiatan produksi atau operasional, yaitu merubah bahan mentah (raw material) atau yang sering disebut unsur masukan (input) menjadi keluaran berbentuk bahan jadi (output) sehingga sesuai dengan kebutuhan konsumen. Setelah diperoleh barang jadi yang berbentuk suatu produk atau jasa yang sesuai dengan yang diharapkan dan dibutuhkan konsumen, sebuah perusahaan dapat memperoleh nilai tambah (added value) dari adanya proses produksi atau operasional tersebut. Adanya additional value inilah yang sebenarnya merupakan keuntungan (profit) bagi sebuah perusahaan. ${ }^{2}$

Agar tujuan perusahaan dapat dicapai sesuai dengan yang diharapkan, maka metode klasik yang selama ini dianggap paling efektif adalah menerapkan konsep miminimasi dan maksimasi. Konsep minimasi adalah usaha menekan biaya (cost) dalam proses produksi atau operasi hanya sesuai dengan yang dibutuhkan, sehingga dengan cost yang lebih kecil maka dapat diperoleh sebuah perbandingan antara penerimaan (revenue) atau profit yang diperoleh dengan pengorbanan yang dikeluarkan akan menjadi lebih tinggi. Konsep maksimasi adalah usaha perusahaan untuk memaksimalkan keluaran (output) proses produksi/operasi dari constrains (kendala-kendala) kelangkaan dan keterbatasan jumlah bahan baku (scarcity) sebagai masukan (input) yang tersedia. ${ }^{3}$

Permasalahan yang timbul adalah pada masa sekarang ini teori dan konsep produksi yang telah menjadi acuan semua perusahaan selama ini sudah banyak yang tidak lagi sesuai dengan kondisi saat ini, yang mana perusahaan yang masih menggunakan teori produksi klasik tersebut pada kenyataannya banyak yang mengalami kesulitan bersaing dengan perusahaan yang menerapkan konsep-konsep mutakhir dalam bidang produksi. Maka pertanyaannya adalah apakah teori dan konsep produksi tersebut masih relevan dengan era revlolusi indutsri 4.0 saat ini? Lalu bagaimanakah strategi dan manajemen produksi yang tepat untuk sekarang ini? Makalah ini berusaha mengungkap bagaimana

\footnotetext{
${ }^{2}$ Musran Munizu, Praktik Total Quality Manajemen (TQM) dan Pengaruhnya Terhadap Kinerja Karyawan (Studi Pada PT. Telkom Cabang Makasar), Jurnal Manajemen dan Kewirausahaan, Vol.12, No.2 2013, 186

${ }^{3}$ Yustina Tritularsih dan Wahyudi Sutopo, Peran KeilmuanTehnik Industri dalam Perkembangan Rantai Pasokan Menuju Era Industri 4.0, Prociding Seminar dan Konferensi Nasional IDEC, 2017.
} 
teori dan konsep produksi mengalami pergeseran sedemikian cepat, sehingga tidak lagi sesuai dengan teori dan konsep produksi klasik.

Mengambil perusahaan telekomunikasi sebagai objek analisisnya, dengan pertimbangan bahwa saat ini produk-produk jasa dari perusahaan telekomunikasi merupakan pemain utama dibidang penyedia layanan jasa seperti pulsa isi ulang, kuota data dan layanan jasa lainnya sudah menjadi salah satu kebutuhan pokok bagi masyarakat saat ini. Pada akhir pembahasan akan disajikan kajian strategi manajemen produksi perspektif ekonomi islam yang disesuaikan dengan objek pembahasan.

\section{Teori produksi}

Secara definisi, produksi adalah kegiatan mengahasilkan sesuatu baik berupa barang, (seperti pakaian, sepatu, makanan), maupun jasa (pengobatan, urut, potong rambut, hiburan, manajemen). Dalam pengertian sehari-hari, produksi adalah mengolah input, baik berupa barang atau jasa, manjadi output berupa barang atau jasa yang lebih bernilai atau lebih bermanfaat.

Seperti tersirat di atas, teori dan faktor produksi di butuhkan untuk melakukan, atau manghasilkan produksi. Kedua hal tersebut diperlukan pengambilan keputusan atau mengetahui bagaimana mengolah faktor-faktor produksi secara optimal, sehingga menghasilkan produksi yang juga optimal. Faktor produksi adalah segala sesuatu yang diperlukan untuk menghasilkan produksi. Faktor produksi ini antara lain meliputi bahan baku, bahan penolong, tekhnologi dan peralatan produksi, tenagan kerja (manusia), dan energi. Untuk dapat melakukan produksi dengan meggunakan faktor produksi ini, perusahaan memerlukan pengorbanan, yang dikenal dengan biaya. ${ }^{4}$

Teori produksi adalah prinsip ilmiah dalam melakukan produksi, yang meliputi:

a. Bagaiman memilih kombinasi penggunaan input untuk menghasilkan output dengan produktivitas dan efisiensi tinggi.

b. Bagaiman menentukan tingkat output yang optimal untuk tingkat penggunaan input tertentu.

\footnotetext{
${ }^{4}$ Arsyad, Lincolin. Ekonomi Manajerial (Ekonomi Mikro Terapan Untuk Manajeman Bisnis. Fakultas Ekonomika \& Bisnis UGM.Yogyakarta.2014, 112.
} 
c. Bagaimana memilih tekhnologi yang tepat sesuai dengan kondisi perusahaan.

Produksi barang dan jasa yang dilakukan diarahkan searah atau mencapai tujuan perusahaa, yaitu mendapat laba. Laba yang didapat perusahaan berasal dari selisih anatara pendapatan (revenue), dengan biaya (cost), oleh karena itu, maka pertimbangan utama atau parameter utama dalam melakukan produksi adalah pendapatan (revenue), yang akan diterima perusahaan dan biaya (cost) yang harus dikeluarkan perusahaan untuk menghasilkan produksi tersebut.

Dalam melakukan analisis terhadap berbagai fenomena ekonomi juga perlu dipahami fungsi-fungsi dalam ekonomi salah satunya adalah fungsi produksi.Fungsi produksi ini ditunjukkan dalam bentuk matematis antar faktor-faktor (input) produksi dengan keluaran (output) produksi. Penggunaan fungsi produksi ini akan membantu para pengambil keputusan produksi untuk mengetahui bangaimana mengolah faktor-faktor produksi secara optimal, sehinngga menghasilkan produksi yang juga optimal. ${ }^{5}$

Dengan kata lain, Fungsi Produksi merupakan sebuah fungsi yang menghubungkan INPUT dengan OUTPUT:

30 Menunjukkan OUTPUT MAKSIMUM yang dapat diproduksi dengan sejumlah INPUT tertentu

31 Menunjukkan INPUT MINIMUM yang digunakan untuk memproduksi sejumlah OUTPUT

32 Fungsi produksi pada umumnya ditentukan oleh TEKNOLOGI yang digunakan

Fungsi produksi (Q) dapat di rumuskan sebagai berikut:

$$
\mathbf{Q}=\mathbf{f}(\mathbf{X}, \mathbf{Y})
$$

Keterangan : $\mathrm{Q}=$ output

$\mathrm{X}, \mathrm{Y}=$ input (input bisa berupa : Capital, Resources, Labour, Technologi, Management) 
Dalam mempelajari teori produksi, ada dua hubungan antara input dan output yang saling berguna bagi pengambilan keputusan manajerial, antara lain:

1 Hubungan antara output denganbeberapa input yang digunakan scara bersama-sama.Hubungan ini dikenal sebagai karakteristik returns to scale dari system produksi. Konsep ini mempengaruhi skala produksi yang optimal atau peluang produksi suatu perusahaan.Konsep ini juga mempengaruhi sifat persaingan dalam suatu industri dan merupakan faktor yang menentukan tingkat profitabilitas dari suatu investasi.

2 Hubungan antara output dengan variasi dari satu input yang digunakan. Istilah produktivitas dan penerimaan suatu faktor produksi digunakan untuk menandai hubungan antara kuantitas suatu input yang digunakansecara individual dengan output yang dihasilkan.

Sedangkan manajemen produksi adalah kegiatan pengambilan keputusan yang berkaitan dengan pengelolaan masukan atau faktor produksi berupa bahan baku, bahan penolong, teknologi, dan manajerial, menjadi produk berupa barang dan jasa yang bernilai lebih produktivitas dan efisiensi yang optimal. Sehubungan dengan kegiatan manajemen produksi, perlu dipahami konsep-konsep produksi seperti Proporsi Penggunaan Input (Fixed or Variable Proportion) ${ }^{6}$

Dalam praktik berproduksi, manajemen harus melihat berbagai kemungkinan atau peluang penggunaan input untuk menghasilkan output yang diinginkan. Oleh karena itu, maka manajemen perlu memikirkan bagaimana kombinasi penggunaan input yang optimal untuk menghasilkan output tertentu, di sampig juga bagaimana mencapai output yang optimal dengan penggunaan input tertentu. Untuk mendapatkan informasi ini perlu di pahami berbagai istilah seperti Produk Total (Total Product, TP), Produk Marjinal (Marjinal Product, MP), dan Produk rata-rata (Averange Product, AP), dari penggunaan input. Berbagai istilah tersebut merupakan informasi yang diperlukan manajemen, dalam mengelola produksi barang dan jasa yang menjadi bisnisnya. ${ }^{7}$

$\checkmark$ Total Produk (TP) merupakan jumlah OUTPUT total yang dihasilkan dari penggunaan sejumlah INPUT tertentu.

${ }^{6}$ Raharja, Prathama. Teori Ekonomi Mikro. Jakarta: FEUI, 2004, 210.

${ }^{7}$ Arsyad, Ekonomi Manajerial... ...127

91 Profit : Jurnal Kajian Ekonomi dan Perbankan 
$\checkmark$ Secara lebih umum, produk total dari suatu faktor produksi bisa ditunjukkan sebagai sebuah fungsi yang menghubungkan output dengan jumlah sumberdaya yang digunakan.

$\checkmark$ Average Product (AP) merupakan produk total dibagi dengan jumlah unit INPUT yang digunakan.

$\checkmark$ Marginal Product (MP) merupakan perubahan OUTPUT yang disebabkan oleh perubahan penggunaan INPUT.

\section{Strategi Manejemen Produksi Perusahaan Jasa Telekomunikasi}

Imu ekonomi mempelajari bagaimana individu dan masyarakat membuat pilihan yang dibatasi oleh berbagai kendala. Berbagai pilihan perlu dibuat karena adanya kelangkaan (scarcity). Kelangkaan menunjukkan terbatasnya sumber daya, seperti terbatasnya tanah untuk mendirikan pabrik, bahan baku, tenaga kerja, dan lainnya. Pengambilan keputusan atas berbagai pilihan yang dibuat oleh manajer sangat berpengaruh terhadap kelangsungan perusahaan dalam menghadapi persaingan.Ekonomi Manajerial adalah aplikasi teori ekonomi untuk keputusan manajerial. Prinsip teori ekonomi adalah optimalisasi atau efisiensi. Optimalisasi adalah memaksimumkan atau meminimumkan sebuah fungsi tujuan, misalnya maksimisasi keuntungan atau minimisasi biaya dengan kendala tertentu. Keputusan manajerial yang tepat akan meningkatkan nilai perusahaan. ${ }^{8}$

Perkembangan industri yang dewasa ini semakin pesat membuat tingkat persaingan menjadi semakin ketat pula. Perusahaan sebagai produsen dalam produksinya senantiasa berebut konsumen dan berusaha menjadikan produknya semakin diminati. Persaingan tersebut tidak dapat dihindari oleh perusahaan, dengan demikian produsen harus berusaha agar tetap bisa bersaing dan bertahan. Produsen perlu memperhatikan beberapa hal di dalam produksinya untuk menghadapi persaingan. Manajerial produksi mutlak diperlukan untuk eksisitensi sebuah perusahaan dalam mempertahankan eksistensinya.

Secara umum, permasalahan produksi adalah memaksimumkan atau meminimumkan sebuah fungsi-fungsi produksi dengan pertimbangan tertentu. Perusahaan

8Dr T Sunaryo, “Konsep Dasar Ekonomi Manajerial,” t.t., 41.

92 Profit : Jurnal Kajian Ekonomi dan Perbankan 
memaksimalkan jumlah produk dengan kendala sejumlah dana tertentu atau perusahaan meminimumkan biaya untuk memproduksi sejumlah produk tertentu. Memaksimumkan atau meminimumkan sebuah fungsi dengan kendala tertentu disebut optimalisasi. Optimalisasi yang dilakukan perusahaan telekomunikasi, diantaranya melalui beberapa keputusan yang diambil manajer adalah, bundling, Pulsa dan Jaringan.

\section{StrategiBundling}

Melihat besarnya potensi pasar pada industry telekomunikasi, maka banyak perusahaan telekomunikasi yang kemudian membuat keputusan strategi-strategi dalam memasarkan produk mereka, salah satu strategi yang di ambil adalah bundling.Secara definisi bundling adalah "Product bundling refers to the practice of selling two or more goods together in a package at a price which is below the sum of the independent prices." Dengan strategi bundling tujuan dari produksi dapat di raih secara optimal. ${ }^{10}$ Perusahaan dari beberapa produsan barang yang bermacam-macam dapat memilih untuk menggabungkan barang-barangnya dengan berbagai variasi dengan efisiensi sebagai sebuah alasan. ${ }^{11}$

Menurut Stremersch dan Tellis ( "Product Bundling is the integration and sale of two or more separate products or services at any price". ${ }^{2}$ Artinya, product bundling adalah suatu integrasi dan penjualan dua atau lebih produk yang terpisah pada harga tertentu. Integrasi pada product bundling ini umumnya menyediakan value added (nilai tambah) kepada pelanggan. "Price Bundling is the sale of two or more separate products in a package at a discount, without any integration". Artinya, Price bundling adalah penjualan dua atau lebih produk yang terpisah dalam satu paket harga yang di diskon, atau suatu penawaran dari beberapa produk yang tidak terintegrasi pada tingkat harga yang lebih rendah bila ditawarkan secara terpisah, tanpa adanya integrasi apapun dari produk (tidak terintegrasi

\footnotetext{
${ }^{9}$ Reisinger, Markus. 2004. The Effects of Product Bundling in Duopoly. Jerman:Department of Economics University of Munich.

${ }^{10}$ William James Adams dan Janet L. Yellen, "Commodity Bundling and the Burden of onopoly," The Quarterly Journal of Economics 90, no. 3 (Agustus 1976): 475, https://doi.org/10.2307/1886045.

${ }^{11}$ John Chung-I Chuang dan Marvin A. Sirbu, "Optimal Bundling Strategy for Digital Information Goods: Network Delivery of Articles and Subscriptions," Information Economics and Policy 11, no. 2 (Juli 1999): 14776, https://doi.org/10.1016/S0167-6245(99)00008-6.

${ }^{12}$ Stefan Stremersch dan Gerard J. Tellis, "Strategic Bundling of Products and Prices: A New Synthesis for Marketing," Journal of Marketing 66, no. 1 (2002): 55-72.
} 
artinya bahwa pelanggan tetap dapat menggunakan salah satu produk tersebut tanpa mengurangi fungsi dari produk tersebut).

Product bundling adalah salah satu strategi dalam pemasaran, yang merupakan strategi untuk menggabungkan penjualan beberapa produk menjadi satu paket penjualan dalam satu harga. Salah satu bentuk sales promotion yang sangat populer adalah dengan melakukan promosi penjualan product bundling. Bundling adalah strategi pemasaran dimana penjual menawarkan atau menjual sejumlah produk dalam satu produk atau satu harga. Product bundling juga sering disebut masyarakat Indonesia sebagai paket penjualan. Penjualan atau pemasaran merupakan salah satu kegiatan yang penting dilakukan oleh perusahaan dalam mempertahankan kelangsungan hidup perusahaan untuk berkembang dan mendapatkan profit. Sebenarnya kegiatan pemasaran ini dilakukan jauh sebelum barang atau jasa diproduksi. Pemasaran adalah suatu proses sosial dan manajerial di mana individu dan kelompok memperoleh apa yang mereka butuhkan dan inginkan melalui penciptaan dan pertukaran produk serta nilai dengan pihak lain. ${ }^{13}$

Agar dapat sukses dalam memasarkan suatu barang atau jasa, setiap perusahaan harus menetapkan harganya secara tepat. Harga dipandang oleh sejumlah besar unsur pemasaran sebagai unsur terpenting dalam bauran pemasaran (marketing mix), setelah produk itu sendiri. Harga merupakan satu-satunya unsur bauran pemasaran yang memberikan pemasukan atau pendapatan bagi perusahaan, sedangkan ketiga unsur lainnya (produk, distribusi, dan promosi) menyebabkan timbulnya biaya (pengeluaran). Di samping itu harga merupakan unsur bauran pemasaran yang bersifat fleksibel, artinya dapat diubah dengan cepat. Tingkat harga yang ditetapkan mempengaruhi kuantitas yang terjual. Selain itu secara tidak langsung harga juga mempengaruhi biaya, karena kuantitas yang terjual berpengaruh pada biaya yang ditimbulkan dalam kaitannya dengan efisiensi produksi. Oleh karena penetapan harga mempengaruhi pendapatan total dan biaya total, maka keputusan dan strategi penetapan harga memegang peranan penting dalam setiap perusahaan, melalui bundling diharapkan biaya yang bebankan bisa menjadi lebih optimal.

\section{Strategi diversifikasi Produk Pulsa dan Data Internet}

${ }^{13}$ Philip Kotler dan Garry Armstrong, Dasar-dasar Pemasaran. Jilid 1, Edisi 9 (Jakarta: PT Indeks,2003).7.

94 Profit : Jurnal Kajian Ekonomi dan Perbankan 
Telepon seluler penggunaanya saat ini tidak sekedar untuk sms dan telpon, juga tidak lagi menjadi sesuatu yang eksklusif dikalangan masyarakat. Telepon seluler tidak hanya berfungsi sebagai alat komunikasi. Yang lebih penting dari hal itu, telepon seluler telah menjadi pendukung gaya hidup (life style) mulai dari anak-anak sampai orang tua. Jika dilihat pasar produk seluler Indonesia terhadap populasi jumlah penduduk Indonesia, jumlah nomor pelanggan prabayar yang telah berhasil registrasi ulang maupun registrasi baru hasil rekonsiliasi sampai dengan berakhirnya batas registrasi ulang tanggal 30 April 2018 adalah sebesar 254.792.159 (Dua ratus lima puluh empat juta tujuh ratus sembilan puluh dua seratus limapuluh sembilan) nomor pelanggan. ${ }^{14}$

Penghitungan data pada sistem data kependudukan Ditjen Dukcapil dan data registrasi nomor pelanggan pada masing-masing operator. Angka ini menunjukan angka riil yang ideal jika dikomparasi dengan jumlah penduduk Indonesia yang 262 juta jiwa dan pengguna internet yang berjumlah 143 juta. Angka ini merupakan hasil akhir yang disetujui Ditjen PPI, BRTI, Ditjen Dukcapil dan para operator setelah adanya proses pencocokan dan pemblokiran nomor-nomor yang tidak melakukan registrasi ulang atau yang diregistrasi secara tidak benar.

Segmentasi dan penyebaran pengguna telepon seluler, pertama adalah pengguna di kota-kota besar. Kedua, jumlah pemakai prabayar lebih besar dari pelanggan bulanan atau pascabayar (65\% terhadap 35\%). Ketiga, di kota besar itu sendiri banyak pengguna yang memiliki lebih dari satu nomor. ${ }^{15}$ Penggunaan pulsa oleh wanita $80 \%$ pulsa untuk berbicara urusan keluarga dan teman sedangkan pria hanya 63\%. Ini berarti, bahwa wanita hanya menggunakan 1,4 jam/bulan (dari 7 jam/bulan) berbicara untuk urusan pekerjaan (di luar urusan keluarga dan teman). Sedangkan pria lebih banyak, yaitu sebesar 3,4 jam/bulan (dari 10 jam /bulan). Sebuah studi yang dilangsungkan di Amerika Serikat mengatakan, dalam sehari, perempuan bisa mengucapkan sekitar 20 ribu kata per hari, sementara lelaki sekitar 7 ribu kata per hari. Penyebab perbedaan jauh itu adalah adanya sebuah protein bernama Foxp2 yang jumlahnya jauh lebih banyak di otak perempuan.

\footnotetext{
${ }^{14}$ Kominfo, siaran pers tentang jumlah pelanggan telekomunikasi seluler prabayar, dari https://kominfo.go.id, di akses tanggal 29 Maret 2018.

${ }^{15}$ Andi Maslia Tenrisau Adam, "Analisis Faktor-Faktor Yang Mempengaruhi Permintaan Pulsa Telepon Seluler Wanita Pekerja Di Kota Makassar," t.t., 8.
} 
Menurut para ilmuwan, orang yang di dalam otaknya memiliki protein khusus yang juga disebut "protein berbahasa" itu lebih banyak, maka makin cerewetlah dia. ${ }^{16}$

Jika melihat data seperti di atas, penggunaan pulsa untuk kebutuhan komunikasi adalah sangat urgent, di Indonesia ada beberapa perusahaan yang menyediakan jasa telekomunikasi. Jasa telekomunikasi di Indonesia diantaranya adalah jasa telepon tidak bergerak, jasa telepon seluler, jasa interkoneksi, jasa layanan pesan singkat, faksimili, jasa layanan internet seluler, dan video call. Jasa telekomunikasi merupakan bagian dari kegiatan penyelenggaraan telekomunikasi yang telah diatur oleh Kementerian Komunikasi dan Informatika Republik Indonesia dalam Undang-Undang Telekomunikasi nomor 36 tahun 1999.17

Indonesia merupakan salah satu negara yang menggunakan telekomunikasi dengan menggunakan mobile phone atau handphone terbanyak di dunia.Data menunjukan bahwa penggunaan handphone di Indonesia bahkan mencapai angka 280 juta, melebihi jumlah penduduknya yang berjumlah 260 juta, sehingga telekomunikasi yang ada di Indonesia merupakan salah satu bisnis yang sangat menggiurkan dan cukup menjajikan akhir - akhir ini.Urutan pertama perusahaan telekomunikasi terbesar di Indonesia adalah perusahaan operator yang menguasai di lapangan yaitu PT Telekomunikasi Selular (Telkomsel). Telkomsel adalah perusahaan operator GSM pertama di Indonesia, berdiri sejak 1995. Dengan perkembangan perusahaan serta inovasi yang di buat, pada tahun 2014, Telkomsel menjelma menjadi perusahaan telekomunikasi terbesar dengan 140 juta pelanggan dan pangsa pasar sebesar 52\% per Januari 2007.Daftar perusahaan telekomunikasi terbesar keduadi Indonesia selanjutnya adalah PT XL Axiata Tbk. Perusahaan ini merupakan perusahaan operator seluler yang beroperasi sejak Oktober 1996, setahun setelah Telkomsel mendirikan perusahaan mereka. XL Axiata juga merupakan perusahaan seluler swasta di Indonesia. Perusahaan ini dimiliki sebanyak 66,43\% oleh Axiata Group dan sisianya, 33,57\% menjadi milik publik.Ketiga, daftar perusahaan telekomunikasi terbesar di Indonesia lainnya adalah PT Indosat Tbk (Indosat Ooredoo). Perusahaan ini sama dengan Telkomsel dan XL, berjalan dan sebagai penyedia jasa dan jaringan telekomunikasi di Indonesia. Pada tahun 2011, Indosat Ooredoo

\footnotetext{
${ }^{16}$ Zahra Sabita, Wanita bicara 20.000 kata sehari. www.kompasiana.com, di akses tanggal 29 Maret 2018. ${ }^{17}$ Undang-undang nomor 36 tahun 1999 tentang Telekomunikasi 
menguasai $21 \%$ pangsa pasar, dan mempunyai pelanggan sebanyak 58,5 juta untuk penggunaan handphone. 18

Melihat besarnya pengguna telepon selular mengindikasikan juga besarnya konsumsi pulsa. Perusahaan penyedia jasa layanan telekomunikasi tentunya akan bersaing dalam memasarkan produknya agar diterima oleh konsumen. Maka harga yang ditawarkan pada konsumen sangat berpengaruh terhadap perkembangan perusahaan penyedia jasa layanan telekomonimasi, termasuk juga penyedia layanan koneksi internet (provider). Jadi perusahaan penyedia jasa telekomuniukasi bersaing dalam menetapkan harga pulsa telepon dan pulsa paket data. Agar dapat sukses dalam memasarkan suatu barang atau jasa, setiap perusahaan harus menetapkan harganya secara tepat. ${ }^{19}$

Harga seringkali digunakan sebagai indikator nilai bilamana harga tersebut dihubungkan dengan manfaat yang dirasakan atas suatu barang atau jasa. Nilai (value) dapat didefinisikan sebagai rasio antara manfaat yang dirasakan terhadap harga. Dengan demikian dapat disimpulkan bahwa pada tingkat harga tertentu, bila manfaat yang dirasakan konsumen meningkat, maka nilainya akan meningkat pula, dan sebaliknya. Pada dasarnya ada empat jenis tujuan penetapan harga: ${ }^{20}$

a. Tujuan Berorientasi pada Laba

Asumsi teori klasik menyatakan bahwa setiap perusahaan selalu memilih harga yang dapat menghasilkan laba paling tinggi. Tujuan ini dikenal dengan istilah maksimisasi laba. Artinya bahwa perusahaan akan mengabaikan harga pesaing. Pilihan ini cocok diterapkan dalam kondisi tidak ada pesaing, perusahaan beroperasi pada kapasitas produksi maksimum, dan harga bukanlah merupakan atribut yang penting bagi pembeli.

b. Tujuan Berorientasi pada Volume (Volume Pricing Objectives)

Harga ditetapkan sedemikian rupa agar dapat mencapai target volume penjualan, nilai penjualan atau pangsa pasar. Pemilihan tujuan ini berorientasi pada volume dan stabilisasi, di mana perusahaan harus dapat menilai tindakan pesaing.

c. Tujuan Berorientasi pada Citra

\footnotetext{
${ }_{18}$ Anonim, Daftar perusahaan telekomunikasi terbesar di Indonesia. http://forum.detik.com/ di akses tanggal 29 Maret 2018.

${ }^{19}$ Fandy Tjiptono, Strategi Pemasaran (Yogyakarta: Andi.1997).151-152.

${ }^{20}$ Ibid.
}

97 Profit : Jurnal Kajian Ekonomi dan Perbankan 
Citra (image) suatu perusahaan dapat dibentuk melalui strategi penetapan harga. Perusahaan dapat menetapkan harga tinggi untuk membentuk atau mempertahankan citra prestisius. Sementara itu harga rendah dapat digunakan untuk membentuk citra nilai tertentu (image of value). Dalam tujuan ini perusahaan berusaha menghindari persaingan dengan melakukan diferensiasi produk atau dengan melayani segmen pasar khusus.

d. Tujuan Stabilisasi Harga

Dalam pasar yang konsumennya sensitif terhadap harga, bila suatu perusahaan menurunkan harganya, maka para pesaingnya harus menurunkan pula harga mereka. Tujuan ini didasarkan pada strategi menghadapi atau memenuhi tuntutan persaingan.

e. Tujuan-tujuan Lainnya

Harga dapat pula ditetapkan dengan tujuan mencegah masuknya pesaing, mempertahankan loyalitas pelanggan, mendukung penjualan ulang, atau menghindari campur tangan pemerintah. Organisasi juga menetapkan tujuan partial cost, recovery, full cost recovery, atau untuk menetapkan social price. Konsumen Menurut Switcher atau price buyer lebih memperhatikan harga didalam melakukan pembelian). Ciri yang paling nampak dari jenis pelanggan ini adalah konsumen membeli suatu produk karena harganya murah. ${ }^{21}$ Ciri yang paling nampak dari jenis pelanggan ini adalah konsumen membeli suatu produk karena harganya murah. Harga seringkali merupakan faktor penting bagi konsumen yang sensitifharga. Peng-iklan sering menggunakan model perbandingan harga untuk menarik perhatian para konsumen lama terhadap merek dan untuk menarik konsumen baru. Caranya adalah dengan meyakinkan mereka bahwa untuk membeli jumlah yang sama dari produk akan menghabiskan lebih sedikit uang, dengan cara ini diharapkan konsumen akan berpindah merk. ${ }^{22}$

Kepuasan atau ketidakpuasan pelanggan adalah respon pelanggan terhadap ketidaksesuaian yang dirasakan antara harapan sebelumnya dan kinerja aktual layanan setelah memakainya. Bila pelanggan merasa puas maka akan memberikan dorongan yang besar untuk melakukan pembelian ulang begitu pula sebaliknya. ${ }^{23}$ Kepuasan pelanggan

\footnotetext{
${ }^{21}$ Rangkuti, Freddy, The Power of Brands, (Jakarta: PT Gramedia Pustaka Utama.2002).

${ }^{22} \mathrm{~m}$ Roby Jatmiko, "Analisis Pengaruh Promosi, Harga, Dan Atribut Produk Terhadap Perpindahan Merek (Brand Switching) Kartu Seluler" 8 (2017): 12.

${ }^{23}$ David K Tse And Peter C Wilton"Models of Customer Satisfaction Formation : An Extension". Journal of Marketing ResearchVol. 25, May 1988; p.204-212.
} 
didefinisikan sebagai evaluasi pasca konsumsi bahwa suatu alternatif yang dipilih setidaknya memenuhi atau melebihi harapan. ${ }^{24}$ Kepuasan dan ketidakpuasan pelanggan merupakan bagian dari pengalaman pelanggan terhadap suatu produk yang ditawarkan. Berdasarkan pengalaman yang diperolehnya pelanggan memiliki kecenderungan untuk membangun nilai-nilai ekspektasi tertentu. Nilai ekspektasi tersebut akan memberikan dampak bagi pelanggan untuk melakukan perbandingan terhadap kompetitor dari produk yang pernah dirasakannya. Secara langsung penilaian tersebut akan mempengaruhi pandangan dan penilaian pelanggan terhadap perusahaan competitor

Hal yang penting bagi konsumen untuk menyampaikan komentar, saran, kritik, pertanyaan maupun keluhan. Paling tidak ada empat aspek penanganan keluhan yang penting yaitu :

1. Empati terhadap pelanggan yang marah.

2. Kecepatan dalam menangani keluhan.

3. Kewajaran atau keadilan dalam memecahkan permasalahan/keluhan

4. Kemudahan bagi konsumen untuk menghubungi perusahaan.

Kualitas layanan didefinisikan sebagai penilaian pelanggan atas keunggulan atau keistimewaan suatu produk atau layanan secara menyeluruh. ${ }^{25}$ Kualitas pelayanan terutama untuk sector jasa selalu diidentikkan dengan mutu usaha itu sendiri. Semakin baik dan memuaskan tingkat pelayanannya maka akan semakin bermutu usaha tersebut begitu pula sebaliknya. Sehingga usaha untuk meningkatkan pelayanan selalu dilakukan agar dapat memaksimalkan kualitas jasa. Pengalaman menggunakan pengetahuan tentang tingkatan suatu produk atau layanan merupakan faktor penentu yang penting bagi pelanggan dalam menilai kinerja produk atau layanan.

Jadi faktor utama yang menentukan dalam penetapan harga adalah tujuan utama pemasaran perusahaan. Tujuan tersebut bisa berupa maksimisasi laba, mempertahankan kelangsungan hidup perusahaan, meraih pangsa pasar yang besar, menciptakan kepemimpinan dalam hal kualitas, mengatasi persaingan, melaksanakan tanggung jawab sosial, dan lain-lain.

\footnotetext{
${ }^{24}$ James F Engel, Roger D. Blackwell and Paul W. Miniard, Consumer Behavior 6 th edition (New York, Dryden Press.1993).231.

${ }^{25}$ VA Zeithaml, Parasuraman, A and Berry LL,"Delivering Quality Service Balancing Customer Perceptions and Expectations", (, New York :The Free Press.1988).3.

99 Profit : Jurnal Kajian Ekonomi dan Perbankan
} 


\section{Strategi Penguatan Jaringan}

Perkembangan industri yang dewasa ini semakin pesat membuat tingkat persaingan menjadi semakin ketat pula. Perusahaan senantiasa berebut konsumen dan berusaha menjadikan produknya semakin diminati. Persaingan tersebut tidak dapat dihindari oleh perusahaan, dengan demikian perusahaan harus berusaha agar tetap bisa bersaing dan bertahan. Persaingan industri telekomunikasi sudah mencapai posisi saturasi, dimana terjadi Zero Sum Game, yakni ketika satu operator tumbuh, maka akan memakan pangsa pasar operator lainnya, dalam bahsa lainnya kill or to be killed. ${ }^{26}$ Kreatif dan inovatif menjadi tuntutan sebuah perusahaan khususnya penyedia jasa layanan telekomunikasi.

Demi mendapatkan pelanggan atau bahkan mengakuisisi pelanggan operator lain, berbagai macam program pemasaran dilakukan. Mulai dari promo, sampai penambahan fitur-fitur yang inovatif. Selain itu, dengan banyaknya pelanggan operator seluler di Indonesia, hal ini memacu banyak

operator baru bermunculan untuk bersaing di industri telekomunikasi. Untuk meraih konsumen ataupun loyalitas konsumen, diperlukan layanan jasa telekomunikasi yang memuaskan, salah satu diantaranya adalah adanya jaringan yang bersifat global dan bagus. Kenyataannya, frekuensi untuk coverage terbatas, dan harus terbagi dengan banyaknya operator telekomunikasi di Indonesia. Padahal jika dibandingkan dengan kondisi di negara maju, mereka rata-rata hanya memiliki 3 operator saja. Tentu akan jauh lebih maksimal pelayanannya dibandingkan di Indonesia yang diserbu banyak operator. China yang punya penduduk 1,3 miliar saja hanya punya tiga operator, dan mereka maju. ${ }^{27}$

Di tengah tren masyarakat yang menganut mobile lifestyle, internet memang tidak bisa dipisahkan dari keseharian mereka. Semua serba online. Bahkan tren SMS dan telepon yang identik dengan layanan inti sebuah operator seluler kini sudah

\footnotetext{
${ }^{26}$ Anonim, Telkom dingin aksi Indosat.https://www.indotelko.com/ di akses tanggal 29 Maret 2018.

${ }^{27}$ Artikel ini telah tayang di Kompas.com dengan judul "Konsolidasi di Industri Seluler Dipermudah, Frekuensi Tidak Diambil", https://ekonomi.kompas. com/
} 
bergeser. Rata-rata operator seluler juga mengakui turunnya pendapatan voice and message yang kini lebih banyak beralih ke layanan data atau internet. ${ }^{28}$

Hasil dari studi empiris yang dilaksanakan ETRI (Electronic and Telecommunications Research Institutes) di Korea tahun 2004 menyebutkan, faktor utama penyebab keinginan berpindah pada industri telekomunikasi adalah faktor ketidakpuasan akan kualitas percakapan (jaringan saat menelepon), faktor kualitas percakapan (jaringan saat menelpon) ternyata mempengaruhi ketidakpuasan dan keinginan pelanggan berpindah operator. Hal ini relevan dengan fenomena "rebutan frekuensi" antar operator seluler di Indonesia. Karena semakin banyak operator seluler

bermunculan, perang frekuensi antar operator berimbas pada turunnya kualitas jaringan telepon yang diterima pelanggan sebagai end user.

Berdasarkan hasil penelitian yang telah dilakukan mengenai kekuatan jaringan telekomunikasi terhadap kepuasan konsumen telekomunikasi, sangat mempengaruhi kepuasan pelanggan jasa layanan telekomunikasi. ${ }^{29} \mathrm{Telah}$ banyak penelitian dalam bidang industri jasa yang menguji hubungan antara kualitas pelayanan dengan citra perusahaan melalui kepuasan pelanggan (termasuk kekuatan jaringan komunikasi). Pengujian tentang pengaruh kualitas kinerja produk atau jasa terhadap reputasi merk, kepuasan dan loyalitas pelanggan pada sektor industri jasa seperti asuransi jiwa, perusahaan telepon, perguruan tinggi dan satu sektor industri produk berwujud yaitu pemasok makanan salmon. ${ }^{30}$ Penelitian tersebut menunjukkan bahwa informasi produk atau jasa berpengaruh terhadap reputasi dan kepuasan konsumen, yang pada akhirnya reputasi dan kepuasan akan berpengaruh terhadap loyalitas konsumen.

Pelayanan yang berkinerja tinggi adalah pelayanan yang mampu memuaskan kebutuhan pelanggan atau dengan kata lain mampu melebihi harapan dari pelanggan. Jadi disini kualitas jasa lebih menekankan pada aspek kepuasan

${ }^{28}$ Anonim, Registrasi Mengurangi Nafsu Perang Tarif Operator. https://industri.kontan.co.id/ di akses tanggal 29 Maret 2018.

${ }^{29}$ Win Esti, Nawazirul Lubis, dan Andi Wijayanto, "Pengaruh nilai pelanggan terhadap retensi pelanggan melalui kepuasan," Jurnal Ilmu Administrasi Bisnis 3, no. 1 (2014): 187-96.

${ }^{30}$ Fred Selnes, "A Examination of The Effect of Product Performance on Brand Reputation, Satisfaction and Loyalty. European Journal of Marketing. (1993) Vol. 27 No. 9, p. 19-35.

101 Profit : Jurnal Kajian Ekonomi dan Perbankan 
pelanggan. Kualitas jasa memiliki hubungan yang erat dengan kepuasan pelanggan. Dan pada gilirannya kepuasan pelanggan dapat menciptakan kesetiaan dan loyalitas pelanggan kepada perusahaan yang membedakan kualitas jasa yang memuaskan. ${ }^{31}$

Kepuasan pelanggan sebagai salah satu elemen strategi yang penting dan memiliki efek konstruktif serta proaktif atas peningkatan loyalitas perusahaan. Konstruk kepuasan pelanggan diukur melalui tiga indikator terpilih, yaitu ketepatan janji (komitmen), kedekatan tempat pelanggan, kemampuan untuk membantu pelanggan. Dari hasil studi ini membuktikan kepuasan pelanggan berpengaruh terhadap loyalitas pelanggan. Pihak manajemen atau yang mempunyai kebijakan hendaknya memperhatikan faktor-faktor yang dapat mempengaruhi loyalitas pelanggan seperti persepsi pelanggan terhadap kualitas produk dan kualitas pelayanan serta citra perusahan penyedia jasa telekomunikasi mempengaruhi kepuasan pelanggan.

Telekomunikasi adalah salah satu bisnis yang memberikan pelayanan jasa kepada para pelanggannya. Sebagaimana bisnis lainnya yang bergerak dalam industri jasa, perusahaan telekomunikasi dituntut menunjukkan kinerja, reputasi dan pelayanan yang semakin baik. Oleh karena itu telekomunikasi sebagai entitas bisnis yang bergerak dalam bidang industry jasa harus berorientasi pada kepuasaan pelanggan. Karena pelanggan yang puas merupakan salah satu basis bagi kelangsungan hidup dan perkembangan bisnis perusahaan itu sendiri.

\section{Kajian Ekonomi Islam}

Sebagaimana telah dibahas sebelumnya, bahwa produksi merupakan suatu upaya produsen dalam mengolah input (bahan baku) menjadi output (barang jadi) dengan menggunakan fungsi-fungsi produksi sehingga menghasilkan suatu output yang maksimal dengan input yang minimal. Dalam ekonomi islam, produsen sebagaimana konsumen memiliki tujuan untuk memperoleh maslahah maksimum melalui aktivitasnya. Maka produsen dalam perspektif ekonomi islam bukan hanya semata mengejar keuntungan semata. Sehingga ekpsresi maslahah dalam kegiatan

\footnotetext{
${ }^{31}$ Fornel Anderson dan Lehmann, Consumer Satisfaction, Market Share and Profitability Finding from Sweden, New York, Journal of Marketing; (1994).Vol 58, p. 53 - 66.
} 
produsi tidak hanya berupa keuntungam, melainkan juga berkah yang melekat dalam setiap tahapan proses produksi hingga menjadi barang jadi. ${ }^{32}$

Dimasukannya berkah dalam fungsi produksi berdasarkan realitas bahwa unsur yang mempengaruhi nilai atau harga suatu produk di mata konsumen tidak hanya ditentukan dari adanya berbagai atribut fisik semata, melainkan juga karena adanya nilai (value) yang dipandang berharga oleh konsumen. Atribut fisik yang melekat pada produk misalnya bahan baku, kualitas barang, desain dan lain-lainnya memang menjadi rujukan utama bagi konsumen dalam memilih produk yang akan dikonsumsi, namun ternyata ada atribut non-fisik yang terkadang lebih diperhatikan oleh konsumen seperti, merek, nilai sejarah, keunikan, passion, habit dan kelangkaan. Maka berkah juga bisa jadi masuk kedalam jenis atribut non-fisik yang seharusnya menjadi pertimbangan utama produsen dan konsumen dalam pengambilan keputusan. ${ }^{33}$

Sehingga atribut berkah akan selalu melekat dalam setiap input produksi yang bila diterapkan pada fungsi produksi dalam ekonomi islam dapat dirumuskan sebagai berikut:

$\mathrm{Q}=\mathrm{f}\left(\mathrm{X}^{\mathrm{b}}, \mathrm{Y}^{\mathrm{b}}\right)$

Keterangan :

$\mathrm{Q}=$ output

$\mathrm{X}^{\mathrm{b}} \mathrm{Y}^{\mathrm{b}}=$ input dengan atribut berkah $(\mathrm{b})$

Dengan dimasukkanya berkah dalam setiap input produksi, maka diharapkan output nya pun akan menjadi produk yang memiliki nilai-nilai keberkahan. Menurut Rohmat Subagiyo keberkahan dalam produksi bisa dicapai dengan menerapkan prinsip-prinsip produksi islami ${ }^{34}$ seperti ;

a. Keadilan dan kesamaan dalam produksi Islami

Islam telah memberikan prinsip-prinsip produksi yang adil dan wajar dalam sebuah bisnis di mana mereka dapat memperoleh kekayaan tanpa mengeksploitasi individu-individu lainnya atau merusak kemaslahatan. Sedangkan usaha yang tidak

32 Tim P3EI UII, Ekonomi Islam, Jakarta :Rajawali Pers, 2013, 259

${ }^{33}$ Ibid, 260.

${ }^{34}$ Rohmat Subagiyo, Teori Produksi Islami, http://repo.iain-tulungagung.ac.id/2016 diakses tanggal 31/Maret 2018

103 Profit : Jurnal Kajian Ekonomi dan Perbankan 
adil dan salah, sangat dicela. Usaha semacam ini dapat menimbulkan ketidakpuasan pada masyarakat dan akhirnya menyebabkan kehancuran. Oleh karena itu, sistem ekonomi Islam bebas dari kesewenang-wenangan dan tidak ada eksploitasi model kapitalisme dan komunisme.

b. Memenuhi takaran, ketepatan, kelugasan, dan kebenaran

Dalam produksi, barang pun tidak hanya menghasilkan barang tetapi harus sesuai dengan perbandingan antara harga barang yang ditawarkan dengan kuantitas yang diberikan. Takaran tersebut harus mencapai tingkat mashlahah produksi yang sesuai, tidak melebih-lebihkan atau menguranginya. Karena hal tersebut dapat merugikan diri sendiri dan orang lain. Dalam Islam, hal tersebut harus ada pengawasan melalui kesadaran diri sendiri dan kepedulian terhadap orang yang membutuhkan, bukan hasrat untuk menginginkan sesuatu yang lebih.

c. Menghindari jenis dan proses produksi yang diharamkan dalam Islam

Tidak mendekati hal-hal yang dalam ketentuan islam sudah pasti bahwa itu diharamkan baik pengelolaan, pembentukan, dan pelaksanaannya. Pada konteks ini islam sudah memberi batasan-batasan yang sesuai menyangkut berbagai hal, seperti pencampuran barang haram ke dalam barang produksi dan menggantikan bahan produksi halal dengan yang haram karena berbagai faktor pendukungnya. Semuanya itu dapat terjadi apabila pelaku-pelaku produksi barang tidak menempatkan dengan hati-hati.

Perusahaan telekomunikasi dengan berbagai produknya yang memiliki varian sangat banyak harus memperhatikan aspek-aspek berkah ini bila produknya ingin diapresiasi oleh konsumen, sebab yang terjadi selama ini banyak keluhan dari konsumen yang merasakan kekecewaan karena merasa dijebak dengan berbagai macam varian produk yang sangat banyak sehingga membingungkan bagi konsumen.

Misalnya adalah pembagian kuota internet yang sangat rumit dan memiliki batasbatas waktu yang sangat merugikan bagi konsumen. Misalnya perusahaan telekomunikasi dalam promosinya menyebutkan bahwa dengan harga sekian mendapatkan 10GB, namun ternyata dari 10GB tersebut dibagi-bagi lagi kedalam beberapa varian misalkan kuota untuk musik, kuota main game tertentu, kuota malam, kuota dari jam sekian sampai jam sekian dan masih banyak lagi, sehingga kuota utama yang sebenarnya dapat digunakan 
hanya sebesar 3GB saja yang membuat konsumen merasa dirugikan. Hal ini tentu tidak sesuai dengan prinsip produksi dalam ekonomi islam, karena dalam pandangan konsumen, diberlakukannya pembagian sistem kuota yang rumit dan berbelit-belit tersebut pada prinsipnya hanya ingin menjebak konsumen untuk membeli produk yang sesungguhnya tidak mereka butuhkan.

Dalam islam, strategi produksi semacam ini tentu melangga beberapa prinsip seperti prinsip keadilan, kejelasan takaran dan juga kemubadziran. Menggar prinsip keadilansaksi karena disatu pihak konsumen diperlakukan kurang adil karena membeli produk yang tidak sesuai dengan harapannya. Prinsip kejelasan takaran juga dilanggar karena dalam akadnya konsumen membeli produk seharga yang ditawarkan tetapi realitasnya tidak sesuai dengan yang ditawarkan, karena produk tersebut hanya sebagian saja yang secara normal dapat digunakan oleh konsumen, dan varian produk lainnya terbuang percuma yang secara islam bisa disebut sebagai suatu kemubaziran.

Faktanya adalah beberapa waktu yang lalu terjadi suatu ungkapan kekecewaan konsumen dengan melakukan hack terhadap suatu website provider tertentu dan menyuarakan kekecewaan serta ketidakpuasannya akan sistem pembagian kuota yang sangat merugikan bagi konsumen.

\section{PENUTUP}

Produksi memegang peranan penting dalam sistem ekonomi, sebab tanpa produksi tentu saja roda dan siklus ekonomi tidak akan bergerak. Produksi pada dasarnya adalah mengolah input menjadi output dengan menggunakan faktor-faktor produksi yang secara umum terdiri dari tiga hal yaitu modal, manusia, dan material. Sementara dalam islam teori produksi tidak hanya semata terkait dengan faktor-faktor tersebut, melainkan harus memasukkan juga unsur immateril yaitu dalam bentuk berkah dalam setipa input produksi yang dilakukan, sehingga produk yang nantinya dihasilkan akan memiliki kemaslahatan maksismal.

Dalam dunia indutri telekomunikasi dengan tingkat persaingan yang begitu tinggi, para manajer masing-masing provider berusaha untuk menawarkan produk-produknya yang paling menarik kepada konsumen, seperti produk dengan sistem bundling, diversifikasi kuota internet dan penguatan jaringan. Namun sayangnya dalam beberapa varian produk terdapat unsur-unsur yang secara jelas merugikan konsumen sehingga 
terjadi kekecewaan dari konsumen. Hal ini disebabkan karena para manajer produksi tidak memasukkan prinsip-prinsip prosuksi islami dalam merancang produk-produk mereka, sehingga melanggar prinsip keadilan, kejelasan takaran dan juga kemubadziran.

\section{Daftar Pustaka}

Andi Maslia Tenrisau Adam, "Analisis Faktor-Faktor Yang Mempengaruhi Permintaan Pulsa Telepon Seluler Wanita Pekerja Di Kota Makassar," t.t., 8.

David K Tse And Peter C Wilton"Models of Customer Satisfaction Formation : An Extension". Journal of Marketing ResearchVol. 25, May 1988; p.204-212.

Fandy Tjiptono, Strategi Pemasaran (Yogyakarta: Andi.1997)

Fred Selnes, "A Examination of The Effect of Product Performance on Brand Reputation, Satisfaction and Loyalty. European Journal of Marketing. (1993) Vol. 27 No. 9, p. 19-35.

Fornel Anderson dan Lehmann, Consumer Satisfaction, Market Share and Profitability Finding from Sweden, New York, Journal of Marketing; (1994).Vol 58, p. 53 - 66.

James F Engel, Roger D. Blackwell and Paul W. Miniard, Consumer Behavior 6 th edition (New York, Dryden Press.1993).231.

John Chung-I Chuang dan Marvin A. Sirbu, "Optimal Bundling Strategy for Digital Information Goods: Network Delivery of Articles and Subscriptions," Information Economics and Policy 11, no. 2 (Juli 1999): 147-76, https://doi.org/10.1016/S0167-6245(99)00008-6.

Lincolin, Arsyad, Ekonomi Manajerial (Ekonomi Mikro Terapan Untuk Manajeman Bisnis. Fakultas Ekonomika \& Bisnis UGM. Yogyakarta. 2014.

Kotler, Philip dan Garry Armstrong, Dasar-dasar Pemasaran. Jilid 1, Edisi 9 (Jakarta: PT Indeks,2003).7.

Kominfo, siaran pers tentang jumlah pelanggan telekomunikasi seluler prabayar, dari https://kominfo.go.id, di akses tanggal 29 Maret 2018.

Musran Munizu, Praktik Total Quality Manajemen (TQM) dan Pengaruhnya Terhadap Kinerja Karyawan (Studi Pada PT. Telkom Cabang Makasar), Jurnal Manajemen dan Kewirausahaan, Vol.12, No.2 2013.

Raharja, Prathama. Teori Ekonomi Mikro. Jakarta: FEUI, 2004, 210.

Reisinger, Markus. 2004. The Effects of Product Bundling in Duopoly. Jerman:Department of Economics University of Munich.

Stefan Stremersch dan Gerard J. Tellis, "Strategic Bundling of Products and Prices: A New Synthesis for Marketing," Journal of Marketing 66, no. 1 (2002): 55-72.

Rangkuti, Freddy, The Power of Brands, (Jakarta: PT Gramedia Pustaka Utama.2002).

Roby Jatmiko, "Analisis Pengaruh Promosi, Harga, Dan Atribut Produk Terhadap Perpindahan Merek (Brand Switching) Kartu Seluler" 8 (2017): 12.

Sabita, Zahra, Wanita bicara 20.000 kata sehari. www.kompasiana.com, di akses tanggal 29 Maret 2018. 
Suryani,Tatik, Penguatan Peran Perguruan Tinggi dalam Pemberdayaan Masyarakat di Era Industri 4.0, Procising Seminar Nasional Hasil Pengabdian Masyarakat (SENIAS) Universitas Islam Madura 2018.

Sunaryo, “Konsep Dasar Ekonomi Manajerial,” t.t., 41.

Tritularsih, Yustina dan Wahyudi Sutopo, Peran KeilmuanTehnik Industri dalam Perkembangan Rantai Pasokan Menuju Era Industri 4.0, Prociding Seminar dan Konferensi Nasional IDEC, 2017.

Tim P3EI UII, Ekonomi Islam, Jakarta :Rajawali Pers, 2013, 259

Undang-undang nomor 36 tahun 1999 tentang Telekomunikasi

VA Zeithaml, Parasuraman, A and Berry LL,"Delivering Quality Service Balancing Customer Perceptions and Expectations", (, New York :The Free Press.1988).3.

William James Adams dan Janet L. Yellen, "Commodity Bundling and the Burden of onopoly," The Quarterly Journal of Economics 90, no. 3 (Agustus 1976): 475, https://doi.org/10.2307/1886045.

Win Esti, Nawazirul Lubis, dan Andi Wijayanto, "Pengaruh nilai pelanggan terhadap retensi pelanggan melalui kepuasan," Jurnal Ilmu Administrasi Bisnis 3, no. 1 (2014): 187-96.

Anonim, Telkom dingin aksi Indosat. https://www.indotelko.com/ di akses tanggal 29 Maret 2018.

Anonim, Kompas.com dengan judul "Konsolidasi di Industri Seluler Dipermudah, Frekuensi Tidak Diambil", https://ekonomi.kompas. com/

Anonim, Registrasi Mengurangi Nafsu Perang Tarif Operator. https://industri.kontan.co.id/ di akses tanggal 29 Maret 2018.

Anonim, Daftar perusahaan telekomunikasi terbesar di Indonesia. http://forum.detik.com/ di akses tanggal 29 Maret 2018. 